RESEARCH ARTICLE

\title{
Documenting State Violence: (Symbolic) Annihilation \& Archives of Survival
}

\author{
Gabriel Daniel Solis \\ Texas After Violence Project, US \\ gabe@texasafterviolence.org
}

This essay explores symbolic annihilation in the context of state violence, including policing, incarceration, and the death penalty in the US. Using auto-ethnography to reflect on the work of the Texas After Violence Project (TAVP) and other community-based documentation and archival projects, I argue that the personal stories and experiences of victims and survivors of state violence are critical counter-narratives to dominant discourses on violence, criminality, and the purported efficacy of retributive law enforcement and criminal justice policies and practices. They also compel us to engage with complex questions about victimhood, disposability, and accountability. Building on the work of activists and archivists engaged in liberatory memory work, I also argue that counter-narratives of state violence confront and challenge the social, cultural, and ideological power of symbolic annihilation. Because these counter-narratives are under constant threat of being suppressed, co-opted, or silenced, they are forms of endangered knowledge that must be protected and preserved. Finally, I reflect on 'archives of survival,' repositories of stories and other ephemera of tragedy that contribute to envisioning and achieving transformative justice.

Keywords: state violence; symbolic annihilation; liberatory archives; liberatory memory work; dehumanization; police violence; mass incarceration; death penalty

What are the stories one tells in dark times? How can a narrative of defeat enable a place for the living or envision an alternative future?

Saidiya Hartman, "Venus in Two Acts"

\section{(Symbolic) Annihilation \& Counter-Narratives}

One year after police officer Darren Wilson shot and killed eighteen-year-old Michael Brown in Ferguson, a life-size mannequin of Brown's dead body was exhibited in a fine arts gallery in Chicago's South Side. ${ }^{1}$ The mannequin was cordoned off by orange traffic cones and yellow police tape, and a video of a crying Eartha Kitt singing 'Paint me some black angels now' played nearby on a continual loop. Ti-Rock Moore, the white visual artist who created 'Angelitos Negros,' believed the installation was symbolic of four hundred years of the dehumanization and suppression of Black people in the US. Michael Brown's father, however, felt the installation just 'brought the whole day [of his son's killing] back alive' (Bever 2015). Critic Kristen West Savali wrote that the installation was not art, but 'a crude plagiarism of Darren Wilson's brutality, nothing more' (Savali 2015). After Michael Brown was killed by Officer Wilson, Ferguson police officers left Brown's exposed body in the street for several hours. Patricia Bynes, a Ferguson committeewoman, believes the police did this intentionally, to send a message to the Black community: 'we can do this to you any day, any time, in broad day light, and there's nothing you can do about it' (Bosman and Goldstein 2014). Through her literal re-creation of the death scene, Moore situated Brown as an eternal victim of state violence, symbolically annihilating his young life, the full potential of the stolen years ahead, and the resilience of Black communities that have been under siege by state violence for centuries. As a mannequin on a waxed

\footnotetext{
1 'Angelitos Negros' was part of the 'Confronting Truths: Wake Up!' (2015) exhibit at the Gallery Guichard in Chicago.
} 
gallery floor, Michael Brown was reduced to an artificial corpse with no face and no humanity; a statue of the 'black mortal threat' toppled, neutralized.

'Angelitos Negros' demonstrates how the power of symbolic annihilation resides in its multiplicity and malleability. Sometimes it is hidden beneath the surface. Sometimes it is right in our face. Sometimes, as 'Angelitos Negros' shows, it manifests even with the best of intentions. The concept of symbolic annihilation has been previously theorized in feminist media studies, museum studies, ethnic studies, and public history (Gerbner 1972, Mazon 1984, Tuchman 1978, Eichstedt and Smith 2002). I am interested in symbolic annihilation in the context of state violence, particularly policing, incarceration, and the death penalty in the US. Following Michelle Caswell's work on symbolic annihilation in the context of archives and the construction of memory and historical narratives, I am interested in how symbolic annihilation manifests in the streets, police reports, courtrooms, mainstream media, and even within ourselves. ${ }^{2}$ Symbolic annihilation has been a pervasive and destructive force in the construction of memory and narratives throughout the history of the US, especially as a ruthless tool to suppress, silence, and erase the lives, cultures, and histories of marginalized communities in the aftermath of violence, terror, and annihilation. For example, in a recent historical study of anti-Mexican violence in the Texas borderlands during the early twentieth century, Monica Muñoz Martinez writes:

Politicians, historians, the media, and historical commissions of the early twentieth century all inscribed a celebratory version of events in newspapers, books, lesson plans, museums, and monuments. This version of history was a key ingredient in their nation building. It hid state crimes and disavowed the loss and trauma experienced by residents. Historical institutions neglected to keep adequate records of racially motivated killings and in this way bolstered efforts to erase this period of terror from state history. Records that do exist often label the dead as criminals $(2018,8)$.

The notion that we should interrogate annihilation in its symbolic form might seem to undermine the urgency of actual annihilation; indeed, we are confronted with reports and images of violence and death on a daily basis. Another police shooting. Another inmate found dead in their cell. Another family destroyed. But symbolic annihilation is often a central premise of actual annihilation; they intertwine, overlap, and reinforce one another. They reveal a foundational logic in dominant ideas of justice: killing conceptually makes it much easier to kill actually or justify a killing in the aftermath. While symbolic forms of annihilation might seem purely academic, what I have learned in my work documenting the stories and experiences of people directly impacted by state violence in Texas is that the hunted are always entangled in the symbolicity of the hunt; that violence and trauma are just as real in the simulacrum as they are on our bodies and minds. Symbolic annihilation moves in all directions; it is relentless in its reach and finality.

In a 2017 lecture titled 'Archives Against Annihilation' at the University of Texas at Austin, Professor Caswell discussed how symbolic annihilation is both a way of understanding the widespread absence or misrepresentation of historically marginalized communities in mainstream archives and a tool to construct people of color as dangerous and threatening to justify their actual annihilation. To demonstrate how symbolic annihilation operates before and after actual annihilation, Caswell cited photographs of Cambodian genocide victims at Khmer Rouge death camps, which functioned to criminalize innocent people, and the co-optation of Trayvon Martin's 2012 murder by George Zimmerman as a racist blackface Halloween costume. ${ }^{3}$ The murder of Trayvon Martin and the images of Cambodian prisoners, while from vastly different social and cultural contexts, also reveal the deadly symbiosis between symbolic annihilation and dehumanization. ${ }^{4}$ But if the logic of dehumanization is founded on the refusal to acknowledge the humanity of targeted individuals or groups, the logic of symbolic annihilation assumes the humanity of its target and then works to strip it away.

\footnotetext{
${ }^{2}$ Caswell (2014a) explores symbolic annihilation in mainstream archives in the context of her work with the South Asian American Digital Archive (SAADA), which she co-founded with Samip Mallick. Recognizing that no archival repository was systematically collecting materials related to the long history of South Asians in the US, and that much of that history would be lost without an immediate archival intervention, Caswell and Mallick established an independent nonprofit community-based archive with a mission to document and preserve South Asian American history and culture. For more, see Caswell 2014a; Caswell, Cifor, and Ramirez 2016.

${ }^{3}$ The portraits of the genocide victims are housed at the Tuol Sleng Genocide Museum in Phnom Penh, the former site of the S-21 death camp.

${ }^{4}$ For more on the history of dehumanization, see Smith 2011 \& Bloom 2017.
} 


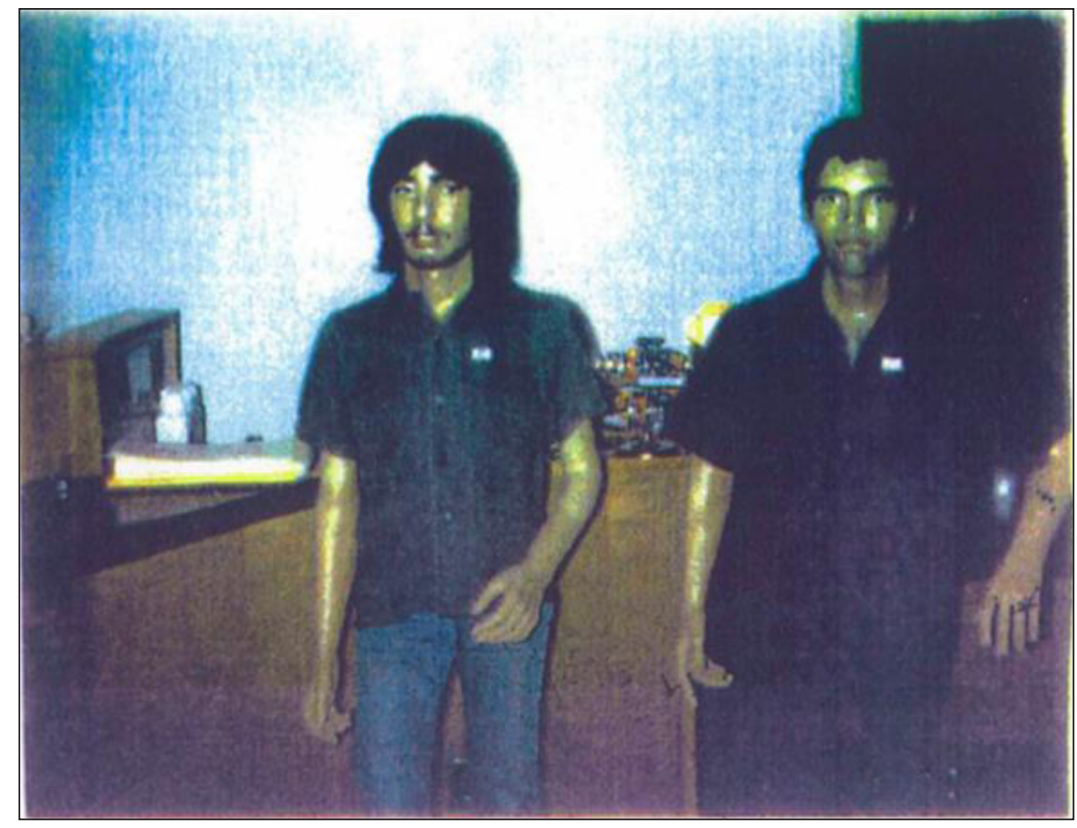

Figure 1: Life-like mannequins of Ricardo Aldape Guerra and Roberto Carrasco Flores commissioned by Harris County prosecutors for Aldape Guerra's 1982 capital murder trial. Photo in author's possession.

Although US courts eventually addressed overt racism and white supremacy in law enforcement and the criminal justice system throughout the twentieth century, today police and prosecutors continue to find ways to effectively dehumanize and symbolically annihilate Black and brown people to make it easier for juries and the general public to condone their social or physical death with little or no moral reluctance. In 2009, the Texas After Violence Project (TAVP) staff attended a training conference for Texas prosecutors and district attorneys on prosecuting capital murder cases. We were sickened by what we saw. In a training session called 'Closing Argument: How to Ask this Jury for Death,' Christy Jack, an assistant district attorney from Tarrant County, taught strategies on how to effectively dehumanize capital defendants so juries would reach unanimous decisions for death. Jack urged prosecutors and district attorneys to appeal to the emotions of jurors by emphasizing the graphic details of the crime, 'number of blows wielded,' 'length of time to die,' and 'slow motion replay.' She also encouraged repeatedly using phrases such as 'There is a chasm that separates him from us,' 'It is not what he did, it is who he is,' and 'He is not like us.'

I have written elsewhere about the 1982 capital murder trial of Ricardo Aldape Guerra, an undocumented Mexican immigrant wrongfully convicted and given a death sentence for the killing of a white police officer in Houston (Solis 2011). Aldape Guerra's story is significant for a number of reasons, but especially for the ways prosecutors portrayed Aldape Guerra to construct him as a dangerous and threatening 'other' that needed to be eliminated. Exploiting heightened public panic about the 'invasion' of Mexicans to the US in the early 1980s, prosecutors Richard Bax and Robert Moen constantly referred to Aldape Guerra as an 'illegal alien' throughout the trial. The prosecutors also commissioned life-like mannequins of Aldape Guerra and Carrasco Flores, who was killed in a shootout with police on the night of the crime. The mannequins, dressed in the men's bloody clothes, stood in the cramped courtroom throughout the trial.

If repeatedly referring to Aldape Guerra as an 'illegal alien' was not enough to try to convince jurors that he posed a threat to white society, the mannequins reinforced the prosecutors' efforts to dehumanize him by providing jurors with an artificial representation of Mexicans as dangerous and subhuman (Figure 1). It worked. Despite a lack of evidence that Aldape Guerra killed the police officer, the jury found him guilty of capital murder and sentenced him to death. After the trial, one of the jurors wrote a letter to the judge saying she was tremendously impacted by the mannequins, which she believed influenced her decision to find Aldape Guerra guilty. 'It was like dead men staring back at me,' the juror wrote (quoted in Solis 2011). The mannequins can be understood as manifestations of the 'Mexican-as-prosthesis' racial ideology that cultural anthropologist Richard Flores has described as 'both metaphor and metonym for larger public discourses on Mexicans in the United States' in which Mexicans are 'incorporated, attached, or added on to

\footnotetext{
${ }^{5}$ PowerPoint slides from the assistant district attorney's presentation were included in a packet of materials provided to all conference attendees, which are in the author's possession.
} 
the project of the nation, not as equal or even lesser subjects but as disembodied arms, backs, hands, and muscle' (Flores 2002: 105). The prosecutors' use of the mannequins to present Aldape Guerra as lifeless, subjectless, and plastic made it easier for the jurors to send him to death since, in a way, he was dead already, or never fully existed.

Outside the courtroom, in the streets, when victims of state violence are people of color, they are almost always portrayed by law enforcement officials and mainstream media as dangerous, threatening, and deserving of the violence against them regardless of the evidence or circumstances. George Zimmerman was acquitted on all charges in his 2014 murder trial because jurors accepted his defense argument that Trayvon Martin, a Black child walking home at night, posed a mortal threat. In 2007, Austin police officer Michael Olsen shot twenty-five-year-old Kevin Brown twice in the back, killing him. Although Olsen admitted that he never saw Brown with a gun, he told investigators that he shot and killed him because he had a look in his eyes like 'he was just going to try to kill me' (quoted in Smith 2007). Olsen lost his job, but never faced any criminal charges. In 2016, Minnesota police officer Jeronimo Yanez shot and killed Philando Castille after Castille politely informed Yanez that he was carrying a legal firearm. Yanez told investigators, 'I thought he was gonna shoot and kill me and kill my partner' (quoted in Smith 2017). Yanez was acquitted on all charges. After Officer Darren Wilson shot and killed Michael Brown in 2014, Wilson described Brown in his grand jury testimony as having a face 'like a demon,' 'grunting,' and 'bulking up to run through the shots' (Sanburn 2014). Wilson was not indicted. This happens even when people of color are victims of terroristic violence. In March 2018, a white serial bomber named Mark Anthony Conditt left several package bombs at random homes across Austin, Texas, where I live with my family. After the first bomb placed at a home on the east side killed Anthony Stephen House, a thirty-nine-year-old Black man, police did not initially investigate his death as a homicide because they believed House accidentally blew himself up or was involved in drug trafficking. ${ }^{6}$

In an incisive essay on Black women, mental illness, and police violence, cultural anthropologist and TAVP interviewer Celeste Henery (2017) interrogates the gendered dynamics of symbolic annihilation and dehumanization, bringing critical attention to the ways law enforcement officials, justice systems, and mainstream media stereotype Black women as masculine and 'crazy' in order to justify their killings. Henery reflects on the police shootings of Charleena Lyles in Seattle, Eleanor Bumpurs and Deborah Danner in the Bronx, and Sophia King in Austin, all Black women who were described in police reports and mainstream media as 'crazy,' aggressive, and dangerous. Police and media reports also emphasized the women's nudity, height, and weight. 'The focus on these women's bodies suggests that they were able to move in ways that defied normative ideas about women's physicality,' Henery writes: 'It implied that they were calculating and thus responsible for their own deaths.'

Magnified by black skin, their bodies and actions are suspect of irrational states of mind: their movements unpredictable and threatening, their laughter possibly a sign of madness, their dissent or anger, aggressive. The idea of crazy reduces black women's presence to perceptions of being socially destructive, and thus unworthy of protection or societal compassion. (Henery 2017)

Since 2007, TAVP has documented, archived, and shared hundreds of oral histories with people directly impacted by violent crime, police shootings, in-custody deaths, incarceration, and the death penalty. ${ }^{7}$ TAVP uses trauma-centered oral history interviews as a research method because it honors the power and agency of narrators to tell their stories in their own words, in their own ways, without fear of judgement, reprisal, or co-optation. The principles and ethics of oral history make it an effective method to document the impacts of violence and trauma because it rejects the power dynamics and adversarial nature of forms of interviewing that typically occur in the aftermath of violence (e.g., police investigative interviews, jail intake interviews, and trial cross-examinations). To conduct trauma-centered oral histories in the aftermath of violence is to bear witness with compassion, authenticity, and understanding, and to create space for narrators to tell the stories of their lives with dignity, meaning, and trust.

What result are personal testimonies that reveal the deep and widespread impacts of violence on physical, psychological, and community health; impacts that are often obscured by an overreliance on statistics. For

\footnotetext{
${ }^{6}$ For more on the 2018 Austin bombings, see Benjamin Wallace-Wells, 'The Inscrutable Terror of the Austin Bombings,' The New Yorker, March 28, 2018, https://www.newyorker.com/news/dispatch/the-inscrutable-terror-of-the-austin-bombings.

7 To watch these video oral histories, visit TAVP's digital archive at the Human Rights Documentation Initiative: http://av.lib.utexas. edu/index.php?title=Category:Texas_After_Violence_Project.
} 
example, data about gun violence in Chicago in 2017 show that the year ended with fewer homicides and shootings than the year before, but the number of homicides and shootings were still among the highest in the nation. What this data cannot show are the impacts of gun violence on the bodies and minds of victims, survivors, and witnesses. 'We do a great job of counting the dead. Their ages, when and where they were killed,' writes journalist Trymaine Lee, '[b]ut we do a terrible job at counting the survivors. Not those who physically cheated death, but those who have been emotionally cheated by death' (Lee 2017).

Before I returned to TAVP in 2016, where I previously worked from 2008-10, I was a capital mitigation specialist at the Office of Capital and Forensic Writs, a post-conviction appellate service that represents death-sentenced defendants in their state habeas proceedings. While at OCFW, I had the opportunity to be trained by Scharlette Holdman, who pioneered capital mitigation in the 1970s after the US Supreme Court reinstated the death penalty. ${ }^{8}$ Holdman helped create the guidelines that mandate capital defense teams to comprehensively investigate the life and social histories of defendants facing execution by exhaustively collecting records, conducting in-depth interviews, and uncovering compelling mitigation narratives that might convince juries to spare defendants' lives. Holdman understood the power of counter-narratives in the courtroom and in the streets; at the time of her death in 2017, Holdman had been interested in putting together a rapid response team of mitigation investigators to travel to sites of lethal police shootings to help victims' loved ones counter false and dehumanizing narratives perpetrated by law enforcement officials and mainstream media. ${ }^{9}$ Growing up in the deep South in the 1950s, Holdman witnessed the power of symbolic annihilation and dehumanization. Devoting her life to defend those accused of the most heinous crimes confirmed what Holdman already understood: it is much harder for us to annihilate the 'other'symbolically or actually-when we see humanity in them, how they loved and were loved. When we look into the crosshairs only to discover that we are actually looking in the mirror.

TAVP is part of a growing cohort of community-based projects across the US that document, archive, and disseminate counter-narratives of state violence. In Chicago, We Charge Genocide is a volunteer-run organization that documents the experiences of young people targeted by police violence and seeks to address the unequal access to power and resources in their communities, which results in the use of police violence 'to silence, isolate, control and repress low-income people and young people of color of color in particular' (We Charge Genocide, n.d.). The Youth/Police Project, also in Chicago, is a collaboration of the University of Chicago Law School and the Invisible Institute that aims to bring attention to the reality of Black teenagers' experience with police by employing a straightforward yet often overlooked approach: 'We ask Black high school students to describe their interactions with police. And we listen' (Futterman, Hunt and Kalvin 2016). In Cleveland, archivists and local activists launched A People's Archive of Police Violence, a community-based archive that 'collects, preserves, and shares the stories, memories, and accounts of police violence as experienced and observed by citizens of Cleveland' (Williams and Drake 2017). A People's Archive uses oral history interviews and a sustainable post-custodial archival model that allows people impacted by police violence to share their stories for future generations. Launched in 2009, the Forced Trajectory Project works with families of police shooting victims that are often forced to become activists, spokespeople, and investigators in their quest for truth and justice. The project uses oral history, photography, and other multimedia to "paint an intimate and accurate portrait of the "forced trajectory" these family members find themselves on after their loved one is killed' (Forced Trajectory Project 2018). In a recent essay on counternarratives to police violence, Tzun writes, '[f]or the survivors of police violence to be able to take control of their narratives before police release official statements to the media challenges the imbalanced power dynamic' (2017).

The personal stories, memories, and perspectives of victims and survivors of state violence are critical counter-narratives to central questions: What happened? Why did it happen? What does it mean? What constitutes real justice, and how do we achieve it? When a person is killed by police or dies in jail or prison custody, their loved ones often distrust or dispute the 'official' narrative. The need to know the truth about how and why people die during interactions with police or while incarcerated has mobilized communities across the US to demand the immediate release of unredacted state-generated records and unedited video footage from body cameras, dash cams, and closed-circuit cameras. In Chicago, police officer Jason Van Dyke

\footnotetext{
${ }^{8}$ For more on Holdman's life and work, see Maurice Chammah, 'Scharlette Holdman, a Force for the Defense on Death Row, Dies at 70,' New York Times, July 22, 2017, https://www.nytimes.com/2017/07/22/us/scharlette-holdman-dead.html.

${ }_{9}$ This point comes from friend and collaborator Amanda Woog, former director of the Texas Justice Initiative. For more on the increased use of 'excited delirium' by police in the aftermath of in-custody deaths, see Michael Barajas, 'Excited. Delirious. Dead,' Texas Observer, October 16, 2017, https://www.texasobserver.org/excited-delirious-dead/.
} 
was charged with the 2014 murder of seventeen-year-old Laquan McDonald only after the city was forced to release dash cam footage of the shooting thirteen months later. Police officers on the scene reported to investigators that McDonald lunged at them with a knife, but the video shows McDonald walking away from the officers as Van Dyke shoots him sixteen times (Meisner, Crepeau, Gutowsky 2018). Van Dyke is currently on trial.

In many cases, it is the digital records created by bystanders that have countered or disproven 'official' narratives of lethal state violence. Bystander cell phone footage showing North Charleston police officer Michael Slager shooting Walter Scott in the back as he ran away and then placing his Taser near Scott's body disproved Slager's account that he shot Scott because he was in 'total fear' for his life. In 2017, two years after the shooting, Slager was convicted of second-degree murder and sentenced to twenty years in prison (Blinder 2017). The susceptibility of state-generated records related to state violence to manipulation or destruction make their immediate public release all the more urgent. Consider, for example, the July 2017 request from US Immigration and Customs Enforcement (ICE) to the National Archives and Records Administration (NARA) to destroy detainee records related to in-custody deaths, sexual assault, and the use of solitary confinement (Washington 2017). Or the manufacturing of police records by the New Orleans Police Department in the aftermath of Hurricane Katrina to justify the use of deadly force against unarmed citizens (Drake 2014). Even when state-generated records are not physically manipulated or destroyed, the frequent use in 'official' narratives of phrases such as 'justifiable homicide,' 'response to resistance, ' 'failure to obey police orders,' and 'excited delirium' linguistically manipulates and destroys records of state violence. ${ }^{10}$

In a landmark study on the reporting of incidents of police brutality by mainstream media outlets, Regina Lawrence (2000) found that reports generally favor police versions of use-of-force incidents that shift the blame to the alleged 'wrongdoer' and away from critical analysis on systemic inequities in US policing. An important precursor to Lawrence's study is the classic text Policing the Crisis (1978), which revealed the 'systematically structured over-accessing to the media of those in powerful and privileged institutional positions' that results in reproducing 'symbolically the existing structure of power in society's institutional order' (Hall et al. 53). 'This is what Becker has called the hierarchy of credibility,' Hall, Critcher, Jefferson, Clarke, and Roberts write:

The likelihood that those in powerful or high-status positions in society who offer opinions about controversial topics will have their definitions accepted, because such "spokesmen" are understood to have access to more accurate or more specialized information on particular topics than the majority of the population. (Hall et al. 1978: 53)

None of this is surprising; the point is that instant global communication and social media have turned the 'hierarchy of credibility' upside-down, allowing for the dissemination of counter-narratives of state violence in real time, across the globe. But for all of its potential in uncovering the truth, the quick dissemination of visual records of state violence does not come without serious risks of re-traumatization. In recent years, there has been a growing chorus of activists, writers, and scholars urging us to think carefully about the consequences of circulating and repeatedly viewing graphic images of Black and brown death. Tonia Sutherland (2017) warns that digital records of Black death reduce Black people to 'Black bodies' and to symbols of Black fear and white supremacy. Sutherland also draws our attention to the ways mainstream media and people in positions of power benefit politically, socially, and economically from images of Black death. For Sutherland, to resist the re-inscribing of structural and systemic racism through the use of visual records of Black death, communities must control 'postmortem narratives' through acts of memorialization, ritual mourning, and honoring victims' 'right to be forgotten.'

\section{Archives of Survival \& Transformative Justice}

Because counter-narratives of state violence are under the constant threat of being suppressed, co-opted, or silenced, they are forms of endangered knowledge that must be protected and preserved. However, in addition to significant political, technical, and funding barriers to comprehensively and responsibly documenting,

\footnotetext{
10 There are projects making these critical narrative interventions, such as Blackbird, a group that provides strategic and rapid response organizing support after violence against Black communities. I met Thenjiwe McHarris at the 2018 Open Philanthropy Grantee Convening, where we discussed the importance of quickly disseminating counter-narratives after police shootings. For more about Blackbird, see their grantee profile on the Borealis Foundation website: https://borealisphilanthropy.org/grantee/ blackbird/.
} 
archiving, and disseminating counter-narratives of state violence, there is also an understandable reluctance by victims and survivors to share their stories publicly. Even when victims and survivors are willing to share their stories publicly, it is still endangered knowledge because the lives of victims and survivors of violence are often disrupted, chaotic, or cut short by the deleterious and long-lasting effects of loss and trauma. For 'death row families' whose loved ones have both perpetrated violence and have been sentenced to statesanctioned execution, their lives are buried in experiences of stigma, loss, and multidirectional grief for the victims and their families, for the uncertain fate of their loved one, and for the new trajectories of their own lives (King 2005). In a recent article published by the United Nations Office of the High Commissioner on Human Rights, TAVP founder and board member Walter C. Long warns of the annihilating theme of nobodiness' that often befalls victims and survivors of state violence, particularly the loved ones of prisoners facing state-sanctioned execution:

Through emotional contagion, the message of nobodiness not only can spread its damage horizontally through the trauma-organized system, shaming family, friends, and advocates of the defendant, but also vertically, dangerously affecting the next generation and setting the stage for traumatic repetition-victimization or perpetration (or both) in next generations through trans-generational transmission of trauma. (Long 2016: 316)

When I think about 'traumatic repetition' in the aftermath of other forms of state violence, I think about Venida Browder, who died of complications from a heart attack only sixteen months after her son, Kalief Browder, took his own life. Kalief had been jailed on Rikers Island for three years (including two years in solitary confinement) without being convicted of a crime. In the months before his suicide, Kalief had publicly shared his stories of being beaten and abused by guards and inmates at Rikers, which led to Mayor Bill de Blasio's efforts to reform the city's court system (Gonnerman 2015). I think about Erica Garner, daughter of Eric Garner, who died after suffering a heart attack at the age of twenty-seven. In an interview a few weeks before her death, Garner said, 'I'm struggling right now with the stress and everything... it beats you down. The system beats you down to where you can't win.'11 'In the wake of the deaths of black people at the hands of the state-from the police to the prison system-the living are often weighted with a sadness that is too heavy to bear,' writes cultural anthropologist and former TAVP board member Christen Smith. 'The fallout of police violence, not just the chokeholds and baton blows, are killing black women' (Smith 2018).

The silences imposed by trauma signal the urgency of creating sustainable community projects that document, archive, and disseminate the stories, experiences, and perspectives of people directly impacted by state violence. Caswell, along with Marika Cifor and Mario H. Ramirez, argue that community archives have important epistemological, ontological, and social impacts by 'empowering people marginalized by mainstream media outlets and memory institutions with the autonomy and authority to establish, enact, and reflect on their presence in ways that are complex, meaningful, substantive, and positive to them in a variety of symbolic contexts' (2016: 57). In addition to confronting and challenging the social, cultural, and ideological power of symbolic annihilation, memory work related to state violence promotes what Caswell calls 'liberatory archival imaginaries,' the 'dynamic ways in which communities creatively and collectively re-envision the future through archival interventions in representations of the shared past' (2014b: 49). Many of the stories in TAVP's archive include 'liberatory imaginaries,' raise public consciousness, and contribute to broader social movements.

In 2017, I interviewed Sara Mokuria, who witnessed her father being shot and killed by Dallas police officers in 1993, when she was ten years old. Over two decades later, Mokuria is a leader of a local movement to end police violence and co-founder of Mothers Against Police Brutality, a multi-racial, multi-ethnic coalition uniting mothers nationwide to fight for police accountability and police reform. Discussing the impacts of post-traumatic stress on her life and the traumatic impacts of police killings on other families, Mokuria says:

The destruction is so immense and so intense, and we can change it. We have to have the courage to change it and just like slavery, just like lynching, just like Japanese internment camps, just like the genocide of Native Americans-all these different points where this country has made the wrong decision and not done right by people. We have to have the courage to imagine a different world and to create it. That's what Mothers Against Police Brutality is doing. We are changing policies

\footnotetext{
${ }^{11}$ The interview with Erica Garner was conducted by Benjamin Dixon via Skype on December 28, 2017. https://twitter.com/
} BenjaminPDixon/status/946436687588192257. 
today. We're advocating to change policies today to save lives and also creating a vision for a future with a radically different type of police force in our country, and it's going to take all of us. (TAVP interview with Sara Mokuria, 2017)

Caswell, with Anne Gilliland, has also argued for the importance of 'impossible archival imaginaries,' 'hoped-for contents [that] are absent or forever unattainable' that can be 'discerned at both psychological and social levels through personal, community, national and societal imaginings' (2016: 61). As an example, Gilliland and Caswell cite the nonexistent video of Officer Darren Wilson killing Michael Brown as an 'imagined record' that Brown's grieving parents, in demanding that police officers wear body cameras, imbued with the 'capability to establish irrefutable evidence of the truth of their son's murder' (66). They further argue that 'the nonexistent imagined record of Brown's murder has an envisioned aspirational trajectory, advancing well beyond the specificities of the Brown case, to bring about a more just future' (66).

In 2017, I interviewed Melanie Young, the sister of Vincent Young, a thirty-two-year-old Black man who died earlier that year while in custody of the Harris County Jail. According to the Sheriff's department, Young hung himself in his cell with a bed sheet. But the Young family rejects this narrative, offering a counter-narrative that centers on Vincent's past harassments by Houston police officers and Harris County Jail guards, as well as Vincent's telling his family that he would be killed if he returned to Harris County Jail. Since her brother's death, Melanie has led protests outside the Harris County district attorney's office demanding justice for her brother's death (Figure 2). Here, Melanie reflects on what she saw on closed circuit video footage from inside the jail.

They were leading him down the hallway, and the way he was walking-you can read his emotions on his face real well. That was one of the first times that I seen my brother scared. And I seen the way that he was walking. He had shackles on his hand, but he was holding his hand on his left side of his ribs like he was hurting. They went to take him inside of his cell and he assumed position, which is to lift your feet up so they can take off the restraints, and when he went to do that they pushed him inside of his cell and they went in with him. That was the last time I seen my brother alive (TAVP interview with Melanie Young, 2017).

The imagined record of video footage showing officers beating Young to death may not exist, but the family's beliefs about how Young died have aspirational trajectories beyond his death. Like the imagined record of Michael Brown's murder, the imagined record of Vincent Young's murder aspires to bring critical attention to the treatment of inmates in Harris County Jail and in jails and prisons across the US.

Archives of violence thus become archives of survival, engaging in liberatory memory work that supports resilience, healing, and justice. Are archives of survival repositories of truth, or hope, or both? The late Dutch criminologist Herman Bianchi has written that 'the main justification for the existence of repressive procedures is the attempt to find the truth, that old objective of the Inquisition. The means by which the repressive system seeks its truth are overwhelming in their destructive force' (1994: 24). In US justice systems, this is an understatement. Look at the unending waves of violence and trauma perpetuated by

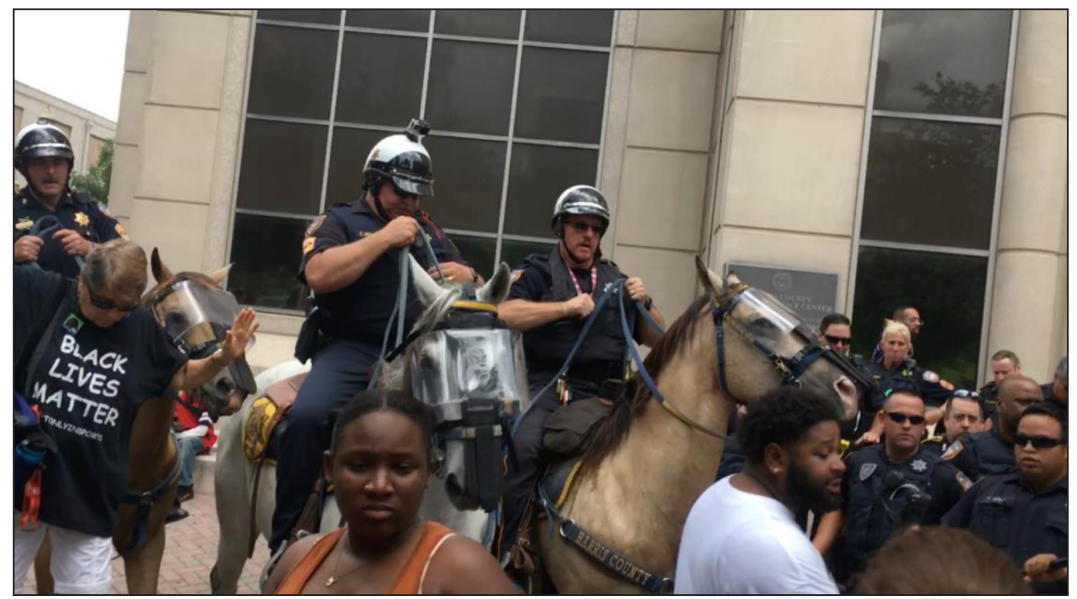

Figure 2: Harris County Sherriff's deputies break up a solidarity protest organized by the family of Vincent Young. July 13, 2017. Photo by the author. 
police investigations, criminal trials, prosecutorial misconduct, solitary confinement, immigrant detention, mass incarceration, and the death penalty. Archives of survival seek truth, but not the 'truth' sought by repressive justice systems. The truths sought by liberatory memory work are raw, relational, revelatory. In addition to offering expansive critiques of our justice systems, counter-narratives of state violence are lived visions and embodied imaginings of a social world that prevents and addresses violence without resorting to counter-violence.

Prison abolitionist Mariame Kaba urges us to always pursue accountability over disposability in the aftermath of harm or violence, which, Kaba argues, is an essential component of transformative justice. Community projects that document, archive, and share counter-narratives of state violence-archives of survival-are also essential to achieve transformative justice. Accountability is truth, justice, existence. Disposability is silence, erasure, annihilation. Countering symbolic annihilation and dehumanization through liberatory memory work is not to prove our own existence. We do it for ourselves. We do it for those who came before us. We do it for those whose lives were cut short. If the logic of dehumanization is to collapse the space between present and past, and the logic of symbolic annihilation is to erase lives, cultures, and histories of marginalized communities, then the logic of our liberatory memory work manifests as a collective affirmation of survival: We are not eternal victims. We are not subjectless mannequins. We have not been defeated. We are stronger than ever.

\section{Conclusion}

The personal stories and experiences of victims and survivors of state violence are critical counternarratives about violence, criminality, and the purported efficacy of current law enforcement and criminal justice policies and practices. Building on the work of activists, advocates, and archivists engaged in liberatory memory work, I argued that counter-narratives of state violence confront and challenge the social, cultural, and ideological power of symbolic annihilation. Counter-narratives of violence compel us to engage with complex questions about victimhood, culpability, and accountability. Because victims and survivors of state violence are often silenced by mainstream archives, justice systems, mainstream media, and early death, and because their stories and perspectives are under constant threat of being suppressed or co-opted, counter-narratives are forms of endangered knowledge that must be protected and preserved. Archives of survival promote transformative justice and prevent and address violence without resorting to counter-violence.

\section{Competing Interests}

The author has no competing interests to declare.

\section{References}

Becker, Howard S. 1978. "Whose Side are We on?" In: The Relevance of Sociology, J. D. Douglas (ed.). New York: Appleton-Century-Crofts.

Bever, Lindsay. 2015. “Artist Defends Art Installation Depicting Michael Brown's Death." Washington Post, July 16. Accessed January 12, 2018. https://www.washingtonpost.com/news/morning-mix/wp/2015/07/16/ artist-defends-art-installation-depicting-michael-browns-death/?utm_term=.7a38135bfa3b. Archived at: https://perma.cc/6ZBL-URRL.

Blinder, Michael. 2017. "Michael Slager, Officer in Walter Scott Shooting, Gets 20-Year Sentence." New York Times, December 7. Accessed February 2, 2018. https://www.nytimes.com/2017/12/07/us/michaelslager-sentence-walter-scott.html. Archived at: https://perma.cc/7X3D-S37U.

Bloom, Paul. 2017. "The Root of All Cruelty?" The New Yorker, November 27. https://www.newyorker.com/ magazine/2017/11/27/the-root-of-all-cruelty. Archived at: https://perma.cc/M4CS-7BKQ.

Bosman, Julie, and Joseph Goldstein. 2014. "Timeline for a Body: 4 Hours in the Middle of a Ferguson Street." New York Times, August 23. Accessed September 1, 2018. https://www.nytimes.com/2014/08/24/us/ michael-brown-a-bodys-timeline-4-hours-on-a-ferguson-street.html?_r=0.

Caswell, Michelle. 2014a. "Seeing Yourself in History: Community Archives and the Fight against Symbolic Annihilation." Public Historian, 36(4): 26-37. DOI: https://doi.org/10.1525/tph.2014.36.4.26

Caswell, Michelle. 2014b. "Inventing New Archival Imaginaries: Theoretical Foundations for Identity-Based Community Archives." In: Identity Palimpsests: Archiving Ethnicity in the US and Canada, Dominique Daniel, and Amalia S. Levi. (eds.). Litwin Books.

Caswell, Michelle. 2017. "Archives Against Annihilation." Harry Ransom Center, University of Texas at Austin, April 12. 
Caswell, Michelle, Marika Cifor, and Mario H. Ramirez. 2016. “'To Suddenly Discover Yourself Existing': Uncovering the Impact of Community Archives." The American Archivist, 79(1): 56-81. DOI: https://doi. org/10.17723/0360-9081.79.1.56

Drake, Jarrett M. 2014. "Insurgent Citizens: The Manufacture of Police Records in Post-Katrina New Orleans and Its Implications for Human Rights." Archival Science, 14(3-4): 365-80. DOI: https://doi.org/10.1007/ s10502-014-9224-2

Eichstedt, Jennifer L., and Stephen Small. 2002. Representations of Slavery: Race and Ideology in Southern Plantation Museums. Washington, DC: Smithsonian Books.

Flores, Richard R. 2002. "Mexicans in a Material World: From John Wayne's The Alamo to Stand Up Democracy on the Border." In: Materializing Democracy: Toward a Revitalized Cultural Politics, Russ Castronovo, and Dana D. Nelson (eds.), 95-115. Durham: Duke University Press. DOI: https://doi. org/10.1215/9780822383901-004

Futterman, Craig B., Chaclyn Hunt, and Jaime Kalvin. 2016. "Youth/Police Encounters on Chicago's South Side: Acknowledging the Realities." The University of Chicago Legal Forum, 5: 125-211. https:// chicagounbound.uchicago.edu/uclf/vol2016/iss1/5.

Gerbner, George. 1972. "Violence in Journalism Drama: Trends and Symbolic Functions." In: Television and Social Behavior, Content and Control, G. A. Comstock, and E. Rubinstein (eds.), 1: 28-187. Washington, D.C.: U.S. Government Printing Office.

Gilliland, Anne J., and Michelle Caswell. 2016. "Records and Their Imaginaries: Imagining The Impossible, Making Possible the Imagined." Archival Science, 16(1): 53-75. DOI: https://doi.org/10.1007/s10502015-9259-z

Gonnerman, Jennifer. 2015. "Kalief Browder, 1993-2015." The New Yorker, June 7. Accessed September 5, 2018. https://www.newyorker.com/news/news-desk/kalief-browder-1993-2015.

Greenwood, Lee. 2009. "Interview with Lee Greenwood." Texas After Violence Project Collection of Oral History Interviews, Human Rights Documentation Initiative, University of Texas Libraries, the University of Texas at Austin. http://av.lib.utexas.edu/index.php?title=TAVP:Lee_Greenwood_1.

Hall, Stuart, Charles Critcher, Tony Jefferson, John Clarke, and Brian Roberts. 1978. Policing the Crisis: Mugging, the State, and Law and Order. New York: Palgrave Macmillan. DOI: https://doi.org/10.1007/978-1-349$15881-2$

Hartman, Saidiya. 2008. "Venus in Two Acts." Small Axe, 12(2): 1-14. DOI: https://doi.org/10.1215/-12-2-1

Henery, Celeste. 2017. "Black Women, Police Violence, and Mental Illness." Black Perspectives, June 28. Accessed January 20, 2018. https://www.aaihs.org/black-women-police-violence-and-mental-illness/. Archived at: https://perma.cc/GER9-LTFX.

King, Rachel. 2005. Capital Consequences: Families of the Condemned Tell Their Stories. Piscataway, NJ: Rutgers University Press.

Lawrence, Regina. 2000. The Politics of Force: Media and the Construction of Police Brutality. Berkeley: University of California Press.

Lee, Trymaine. 2017. "Chicago Trauma: Counting Broken Bodies, But Not Broken Spirits." NBC News, March 31. Accessed May 10, 2018. https://www.nbcnews.com/news/us-news/chicago-trauma-countingbroken-bodies-not-broken-spirits-n740516.

Long, Walter C. 2016. "The Death Penalty as a Public Health Problem." In: Death Penalty and the Victims, Ivan Šimonovic (ed.). New York: United Nations. www.ohchr.org/EN/NewYork/Pages/Resources.aspx.

Mazon, Mauricio. 1984. The Zoot-Suit Riots: The Psychology of Symbolic Annihilation. Austin, TX: The University of Texas Press.

Meisner, Jason, Megan Crepeau, and Christy Gutowsky. 2018. "For two hours, jurors at Van Dyke's trial view photos, hear detailed account of gunshot wounds to Lacquan McDonald." September 19. Accessed September 20, 2018. http://www.chicagotribune.com/news/local/breaking/ct-met-laquan-mcdonaldjason-van-dyke-trial-20180919-story.html.

Mokuria, Sara. 2017. "Interview with Sara Mokuria." Texas After Violence Project Collection of Oral History Interviews, Human Rights Documentation Initiative, University of Texas Libraries, the University of Texas at Austin. http://av.lib.utexas.edu/index.php?title=TAVP:Sara_Mokuria.

Muñoz Martinez, Monica. 2018. The Injustice Never Leaves You: Anti-Mexican Violence in Texas. Harvard University Press.

Sanburn, Josh. 2014. "All the Ways Darren Wilson Described Being Afraid of Michael Brown." Time Magazine, November 25. Accessed January 23. 2018. http://time.com/3605346/darren-wilson-michael-browndemon/. Archived at: https://perma.cc/WVD2-7FF7. 
Savali, Kirsten West. 2015. "An Art Exhibit Revictimizes Michael Brown." The Root, July 15. Accessed December 21, 2017. https://www.theroot.com/an-art-exhibit-revictimizes-michael-brown-1790860510. Archived at: https://perma.cc/N6EN-S5JK.

Smith, Christen. 2018. "The Fallout of Police Violence Is Killing Black Women Like Erica Garner." The Conversation, January 4. Accessed February 20, 2018. https://theconversation.com/the-fallout-of-policeviolence-is-killing-black-women-like-erica-garner-89654. Archived at: https://perma.cc/UJ7L-7DAE.

Smith, David Livingstone. 2011. Less Than Human: Why We Demean, Enslave, and Exterminate Others. New York: St. Martin's Press.

Smith, Jordan. 2007. "Acevedo Fires Olson." The Austin Chronicle, December 7. Accessed February 1, 2018. https://www.austinchronicle.com/news/2007-12-07/568560/. Archived at: https://perma.cc/2HU36SVD.

Smith, Mitch. 2017. "Minnesota Officer Acquitted in Killing of Philando Castille." New York Times, June 16. Accessed February 13, 2018. https://www.nytimes.com/2017/06/16/us/police-shooting-trial-philandocastile.html. Archived at: https://perma.cc/9J7D-SNVY.

Solis, Gabriel Daniel. 2011. "El Corrido de Ricardo Aldape Guerra: Form, History, and Resistance." Cultural Dynamics: Insurgent Scholarship of Culture, Politics, and Power, 23(3): 173-96. DOI: https://doi. org/10.1177/0921374011430567

Sutherland, Tonia. 2017. "Making a Killing: On Race, Ritual, and (Re)Membering in Digital Culture." Preservation, Digital Technology \& Culture, 46(1): 32-40. DOI: https://doi.org/10.1515/pdtc-2017-0025

Tuchman, Gaye. 1978. "Introduction: The Symbolic Annihilation of Women by the Mass Media." In: Hearth and Home: Images of Women in the Mass Media, Gaye Tuchman, Arlene Kaplan Daniels, and James Benet (eds.), 3-38. New York: Oxford University Press.

Tzun, Nissa. 2017. "Forced Trajectories: Creating Counter-Narratives to Police Violence." ArtsEverywhere, October 19. Accessed January 20, 2018. http://artseverywhere.ca/2017/10/19/forced-trajectories/. Archived at: https://perma.cc/CBM9-3BM4.

Washington, John. 2017. "ICE Wants to Destroy its Records of In-Custody Deaths, Sexual Assault, and other Detainee Files." The Nation, September 13. Accessed August 15, 2018. https://www.thenation.com/ article/ice-wants-to-destroy-its-records-of-in-custody-deaths-sexual-assault-and-other-detainee-files/.

Williams, Stacie M., and Jarrett M. Drake. 2017. "Power to the People: Documenting Police Violence in Cleveland." Journal of Critical Library and Information Studies, 1(2). DOI: https://doi.org/10.24242/jclis. v1i2.33

Young, Melanie. 2017. "Interview with Melanie Young." Texas After Violence Project Collection of Oral History Interviews, Human Rights Documentation Initiative, University of Texas Libraries, the University of Texas at Austin. http://av.lib.utexas.edu/index.php?title=TAVP:Melanie_Young.

How to cite this article: Solis, Gabriel Daniel. 2018. Documenting State Violence: (Symbolic) Annihilation \& Archives of Survival. KULA: Knowledge creation, dissemination, and preservation studies 2(1): 7. DOI: https://doi.org/10.5334/ kula.28

Submitted: 24 February 2018

Accepted: 01 August 2018

Published: 29 November 2018

Copyright: ( $) 2018$ The Author(s). This is an open-access article distributed under the terms of the Creative Commons Attribution 4.0 International License (CC-BY 4.0), which permits unrestricted use, distribution, and reproduction in any medium, provided the original author and source are credited. See http://creativecommons.org/ licenses/by/4.0\%.

u[ KULA: Knowledge creation, dissemination, and preservation studies is a peer-reviewed

$\mid \mathrm{u} \quad$ open access journal published by Ubiquity Press. 